\title{
Hematopoiesis in aged female mice devoid of thyroid hormone receptors
}

\author{
Ángela Sánchez ${ }^{1, *}$, Constanza Contreras-Jurado 1,2,*, Diego Rodríguez¹, Javier Regadera³, Susana Alemany ${ }^{1}$ and \\ Ana Aranda1,2 \\ 'Instituto de Investigaciones Biomédicas 'Alberto Sols', Consejo Superior de Investigaciones Científicas and Universidad Autónoma de Madrid, \\ Madrid, Spain \\ ${ }^{2}$ Centro de Investigación Biomédica en Red de Cáncer (CIBERONC), Madrid, Spain \\ ${ }^{3}$ Department of Anatomy, Histology and Neuroscience, Universidad Autónoma de Madrid, Madrid, Spain
}

Correspondence should be addressed to A Aranda or S Alemany: aaranda@iib.uam.es or salemany@iib.uam.es

*(Á Sánchez and C Contreras-Jurado contributed equally to this work)

\begin{abstract}
Hypothyroidism is often associated with anemia and immunological disorders. Similar defects are found in patients and in mice with a mutated dominant-negative thyroid hormone receptor $\alpha(T R \alpha)$ and in knockout mice devoid of this receptor, suggesting that this isoform is responsible for the effects of the thyroid hormones in hematopoiesis. However, the hematological phenotype of mice lacking also TR $\beta$ has not yet been examined. We show here that TR $\alpha 1 / T R \beta$-knockout female mice, lacking all known thyroid hormone receptors with capacity to bind thyroid hormones, do not have overt anemia and in contrast with hypothyroid mice do not present reduced Gata1 or Hif1 gene expression. Similar to that found in hypothyroidism or TR $\alpha$ deficiency during the juvenile period, the B-cell population is reduced in the spleen and bone marrow of ageing TR $\alpha 1 / T R \beta$-knockout mice, suggesting that TR $\beta$ does not play a major role in B-cell development. However, splenic hypotrophy is more marked in hypothyroid mice than in TR\&1/TR $\beta$-knockout mice and the splenic population of T-lymphocytes is not significantly impaired in these mice in contrast with the reduction found in hypothyroidism. Our results show that the overall hematopoietic phenotype of the TRa1/TR $\beta$-knockout mice is milder than that found in the absence of hormone. Although other mechanism/s cannot be ruled out, our results suggest that the unoccupied TRs could have a negative effect on hematopoiesis, likely secondary to repression of hematopoietic gene expression.
\end{abstract}
Key Words
- thyroid hormone receptors
- knockout mice
- hematopoiesis
- spleen
- bone marrow

\section{Introduction}

Hypothyroidism is frequently associated with anemia and immune disorders in humans (Franzese et al. 1996, Pillay 1998, Kawa et al. 2010, Vitale et al. 2010, Bremner et al. 2012, Erdogan et al. 2012) and animals (MontecinoRodriguez et al. 1997, Foster et al. 1999, Angelin-Duclos et al. 2005, Zhang et al. 2017), demonstrating the important role of the thyroid hormones in hematopoiesis.
Most actions of the active thyroid hormone triiodothyronine (T3) are initiated by binding to the nuclear thyroid hormone receptors (TRs), encoded by the TR $\alpha$ and $T R \beta$ genes, which result in several isoforms with different expression and functions (Aranda \& Pascual 2001, Aranda et al. 2013, Pascual \& Aranda 2013). TR $\alpha 1$ and TR $\alpha 2$ are the main TR $\alpha$ proteins, 
with an almost ubiquitous expression, although TR $\alpha 2$ cannot bind hormone and could act as a TR antagonist, at least in transfected cells. TR $\beta 1$ and TR $\beta 2$ are the main thyroid hormone-binding isoforms encoded by TR $\beta$. While TR $\beta 1$ is widely expressed, TR $\beta 2$ has a very restricted pattern of expression. Therefore, TR $\alpha 1$, TR $\beta 1$ and TR $\beta 2$ can account for the majority if not all of TR-dependent thyroid hormone signaling. Targeted disruption in mice of TR $\alpha 1$ (Wikstrom et al. 1998), the entire TR $\alpha$ locus (Fraichard et al. 1997), and TR $\beta$ genes has been performed (Forrest et al. 1996a,b, Gauthier et al. 1999). In addition, double knockout mice lacking TR $\alpha 1 / T R \beta$ or $T R \alpha / T R \beta$ have been generated. These mice are viable and their phenotypic analysis shows that redundancy of TR $\alpha$ and TR $\beta$ is only partial (Gauthier et al. 1999, Gothe et al. 1999).

Both juvenile (Angelin-Duclos et al. 2005) and adult (Kendrick et al. 2008) mice deficient for TR $\alpha$ have low hematocrit levels. A mutant mouse expressing a mutated dominant negative form of TR $\alpha 1$ (denoted as $\mathrm{TR} \alpha 1^{\mathrm{PV} /+}$ mouse) also shows abnormal red blood cell (RBC) indices, and reduced numbers of eryhthroid bone marrow (BM) cells secondary to the impaired capacity of progenitor cells to differentiate to erythroblasts (Park et al. 2017). Importantly, this mutation faithfully reproduces the phenotype seen in patients with equivalent $T R \alpha$ mutations, in which mild anemia and erythroid disorders are found (Bochukova et al. 2012, Moran et al. 2013). Of note, anemia is not a feature of patients with $T R \beta$ mutations (Dumitrescu \& Refetoff 2013).

Young mice lacking TR $\alpha$ show a strong decrease in splenic numbers of B-lymphocytes, T-lymphocytes, macrophages and granulocytes (Arpin et al. 2000), B-cells being the more severely affected as a consequence of a proliferation defect of $\mathrm{B}$ cell precursors in BM (Arpin et al. 2000). Young TR $\alpha$ TR $\beta$ KO mice also display a visible splenic hypotrophy, although less pronounced than that found in congenitally hypothyroid mice (Flamant et al. 2002), while deletion of $T R \beta$ alone does not decrease spleen weight (Angelin-Duclos et al. 2005). This does not imply that TR $\beta$ has no function in hematopoiesis because TR $\beta \mathrm{KO}$ mice have high circulating levels of thyroid hormone and the absence of receptor could be compensated by the excess of ligand. However, a study of the effect of the deficiency of TR $\beta$ together with TR $\alpha$ in adult mouse hematopoietic cell populations has not yet been conducted. To analyze the role of TRs in the generation of blood cells we have used TR $\alpha 1 / T R \beta \mathrm{KO}$ female mice lacking the major receptors with the capacity to bind thyroid hormones and have compared the results with those obtained in hypothyroid mice. To discard that the changes in hematopoiesis could be secondary to a developmental disorder, female animals were made hypothyroid late in life and were examined at adulthood. Our results show that TRs deletion causes a milder hematopoietic phenotype than hypothyroidism. Contrary to that observed in hypothyroid animals, TR $\alpha 1 /$ TR $\beta$ KO animals do not display overt anemia or decreased Gata 1 or Hif 1 gene expression and a reduction of the more differentiated erythroblast population in the spleen appears to be compensated by a normal generation of mature erythroblasts in the BM. In addition, in adult TR $\alpha 1 / T R \beta$-deficient mice there is a reduction of B-cells similar to that found in age-matched hypothyroid mice or in young TR $\alpha 1 \mathrm{KO}$ animals, reinforcing the idea that the B-cell phenotype of hypothyroidism could be mediated by the lack of thyroid hormone binding to TRo1. However, the numbers of splenic T-lymphocytes are not significantly reduced in TR $\alpha 1 / T R \beta \mathrm{KO}$ mice in contrast with the reduction found in hypothyroidism and spleen hypotrophy is less marked in the absence of the receptors. In summary, our results show that mice lacking TRs do not display some of the deleterious effects on erythropoiesis and leukopoiesis found in hypothyroid animals, indicating again the divergent consequences for hormone versus receptor deficiency (Flamant et al. 2002, Flamant \& Samarut 2003). Although given the complex physiology in the whole animal phenotype other mechanisms cannot be excluded, these results are compatible with a repressive action of the unoccupied receptors on hematopoietic gene transcription.

\section{Materials and methods}

\section{Mice}

All animal studies were done in agreement with the European Community Law (86/609/EEC) and the Spanish law (R.D. 1201/2005), with approval of the Ethics Committee of the Consejo Superior de Investigaciones Científicas. Adult female double knockout (KO) mice 9-11 months old lacking TR $\alpha 1$ and all TR $\beta$ isoforms (Gothe et al. 1999) were used. Mice were re-derived to a CD1 genetic background by back-crossing for ten generations with animals obtained from Charles River Laboratories (CD-1® IGS Mouse). Due to the strongly reduced fertility of TR $\alpha 1 / T R \beta$-deficient females (Gothe et al. 1999), double KO males were crossed with TR $\alpha 1^{-/-/ T R \beta^{+/-}}$females. Wild type (Wt) age-paired mice were used as controls. To induce hypothyroidism 9-month-old female mice with the same genetic background were fed during one month with a low iodine diet $+0.15 \%$ propylthiouracil (Ssniff Spezialdiäten $\mathrm{GmbH}$ E15552-24) supplemented with $10 \mathrm{~g} / \mathrm{L}$ potassium 
perchlorate in the drinking water, while control animals were fed with a control diet (E15550-04), in which the same diet without propylthiouracil was supplemented with potassium iodide to contain $1.15 \mathrm{mg} \mathrm{I} / \mathrm{kg}$.

\section{Histological analysis}

Spleen samples were fixed $4 \%$ buffered formalin and embedded in paraffin. Deparaffinized tissue sections $(4 \mu \mathrm{m})$ were stained with $\mathrm{H} \& \mathrm{E}$ or Picrosirius Red to determine spleen morphology.

\section{Cell isolation}

After killing with $\mathrm{CO}_{2}$, bone marrow (BM) cells were extracted from the tibias and femurs by gentle centrifugation at $600 \boldsymbol{g} \times 1 \mathrm{~min}$ and splenocytes were obtained according to the GentleMACS dissociator protocol (http://www. miltenyibiotec.com). Blood was collected from the tail vein and EDTA was added to inhibit clotting.

\section{Hemoglobin measurement}

Mouse peripheral blood hemoglobin was determined (Bian et al. 2016) by lysis of $10 \mu \mathrm{L}$ whole blood in $1 \mathrm{~mL}$ water followed by O.D. reading at $540 \mathrm{~nm}$.

\section{Flow cytometry}

Aliquots of $0.5-2 \times 10^{6}$ splenic or BM cells or $40 \mu \mathrm{L}$ of blood were treated with CD16/32 (2.4G2, Fc block; Cultek) for $20 \mathrm{~min}$ and stained for the surface markers indicated in Supplementary Table 1 (see section on supplementary materials given at the end of this article) for another $20 \mathrm{~min}$ in the dark at RT. For analysis of $\mathrm{CD}^{4} 5^{+}$subpopulations, samples were treated for $10 \mathrm{~min}$ with Versalyse lysing solution (Beckman Coulter) and washed with 2\% FBS and $5 \mathrm{mM}$ EDTA in PBS to eliminate RBC interference. The absolute number of cells was calculated by adding PerfectCount microspheres (Cytognos) to the flow cytometry samples. Live cells were identified by adding DAPI (32670, Sigma-Aldrich) or Sytox Green $10 \mathrm{~min}$ before FACS analysis. Unstained cells were used as a negative control, to establish the flow cytometer voltage settings, and singlecolor positive controls were used to adjust compensation. Cell fluorescence was analyzed using a FACSAria II or FACSCalibur flow cytometer (BD), and the data obtained were analyzed with FlowJo software (Tree Star).

\section{Analysis of apoptosis}

Cells labeled with the appropriate antibodies were stained with Annexin V (A1319, Life Technologies) plus 4',6-diamidino-2-fenilindol (DAPI) and immediately subjected to flow cytometry analysis. Live cells were identified as DAPI-/Annexin $\mathrm{V}^{-}$, cells at the early

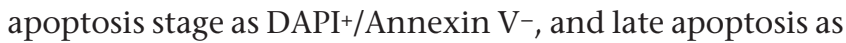
$\mathrm{DAPI}^{+} /$Annexin $\mathrm{V}^{+}$cells.

\section{Quantitative real-time PCR assays of mRNAs}

Total RNA was extracted from BM and spleen using ReliaPrep ${ }^{\mathrm{TM}}$ RNA Tissue Miniprep System (Promega). mRNA levels were analyzed in technical triplicates by quantitative RT-PCR with the primers listed in Supplementary Table 2, following specifications of iScript ${ }^{\mathrm{TM}}$ cDNA Synthesis kit (Bio-Rad) and Power SYBR Green PCR Master Mix. Data analysis was done using the comparative CT method and 18S RNA levels were used as for data correction.

\section{Statistical analysis}

Differences of TR $\alpha 1 / T R \beta$ KO mice with respect to wild-type animals were assessed by using the two-tailed Student's $t$ test or Mann-Whitney test with statistical significance when $P<0.05$. In the figures ${ }^{*} P<0.05$; ${ }^{* *} P<0.01$ and ${ }^{* * *} P<0.001$.

\section{Results}

\section{Double knockout mice lacking TR $\alpha 1$ and TR $\beta$ are not anemic}

Since both hypothyroidism and TR $\alpha$ deletion or mutation cause abnormal erythropoiesis and anemia, we first measured using flow cytometry the number of circulating cells in ageing $T R$ KO mice lacking not only TR $\alpha 1$ but also TR $\beta$, the major thyroid hormone-binding receptor isoforms. Surprisingly, the total number of blood cells showed a tendency to be reduced in TR $\alpha 1 / T R \beta \mathrm{KO}$ mice, but the decrease was not statistically significant with respect to the Wt animals. The same occurred with the number of RBCs identified by expression of the surface marker TER119 (a molecule associated with glycophorin A) (Fig. 1A), gated as shown in Supplementary Fig. 1B. KO mice showed a trend to present lower circulating levels of RBCs but due to the variability of the data, differences were not significant. Hemoglobin content was also the same in Wt and $\mathrm{KO}$ mice (Fig. 1A), and younger adult female animals also had normal RBC numbers (Supplementary Fig. 1A). Therefore, mice deficient in both TR $\alpha 1$ and TR $\beta$ do not display overt anemia. In contrast, one month of treatment with low iodine diet and antithyroidal drugs late in life was sufficient to cause a statistically significant reduction of RBC numbers in mice with the same age, 

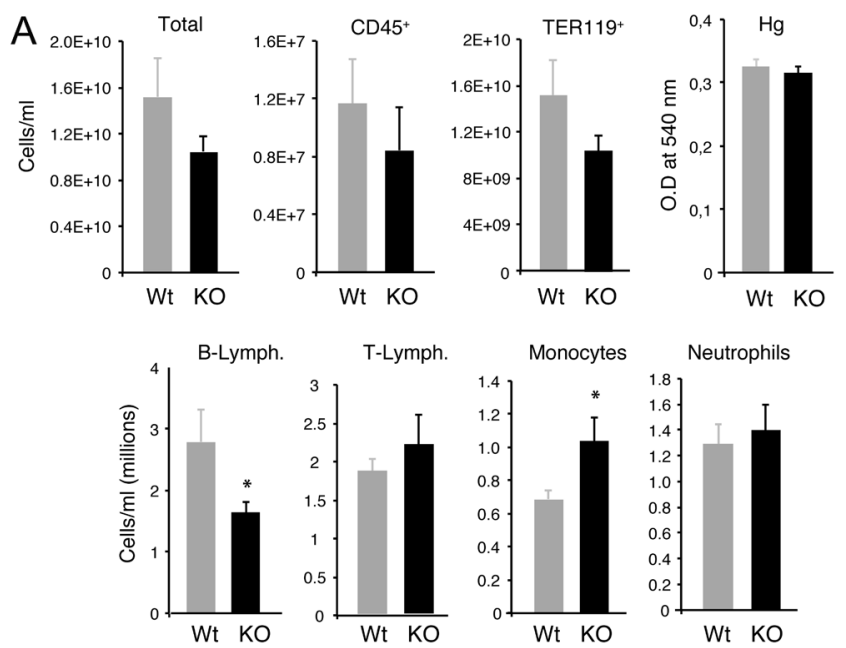

B
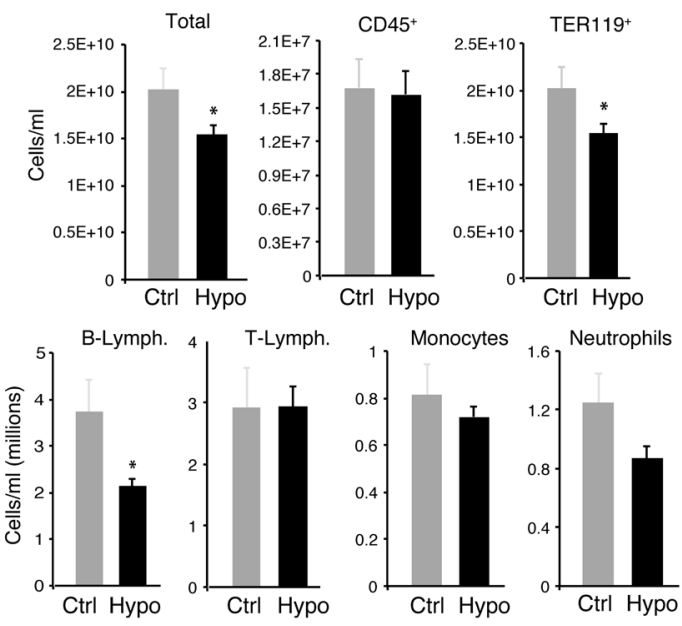

\section{Figure 1}

Analysis of circulating cells in TR-deficient and hypothyroid mice. (A) The total number of alive blood cells, leukocytes (CD45+ cells), RBCs (red blood cells (TER119+) and hemoglobin ( $\mathrm{Hg})$ was estimated in wild type (Wt) $(n=6)$ and knockout (KO) mice devoid of both TR $\alpha 1$ and TR $\beta(n=8)$. After lysis of RBCs, the total number of B-lymphocytes $\left(B 220^{+}\right)$, T-lymphocytes (CD3+), monocytes (CD115') and neutrophils (Lyg6G+) was determined in Wt and KO mice. (B) Number of total TER119 and CD45 positive cells in control (Ctrl) and hypothyroid (Hypo) mice $(n=5)$. Circulating number of B-lymphocytes, T-lymphocytes, monocytes and neutrophils in control and hypothyroid mice are shown in the lower panels. Data are means \pm S.E. $* P>0.05$.

which showed smaller variability (Fig. 1B). This treatment caused an almost total depletion of Deiodinase 1 mRNA levels in the liver (Fig. 3A), a sensitive marker of thyroid hormone action (Zavacki et al. 2005), showing that these animals are profoundly hypothyroid.

As thyroid hormone signaling also appears to be required for the development of other hematopoietic cells (Montecino-Rodriguez et al. 1996, Foster et al. 1999, Arpin et al. 2000, Grymula et al. 2007, Jafarzadeh et al. 2010, Jara et al. 2017), we next evaluated the number of cells expressing the leukocyte common antigen CD45 cell surface marker, finding a normal number of circulating CD45+ cells in TR $\alpha 1 / T R \beta$-deficient and hypothyroid mice (Fig. $1 \mathrm{~A}$ and $\mathrm{B}$ ). We next studied the $\mathrm{CD} 45^{+}$subpopulations, after lysis of erythrocytes and staining with anti-B220, CD3, CD115, and Ly6G antibodies to identify B-cells, T-cells, monocytes and neutrophils, respectively, gated as indicated in Supplementary Fig. 1C. As shown in Fig. 1A and $\mathrm{B}$ the number of circulating B-cells was reduced in $\mathrm{KO}$ and hypothyroid mice, while monocytes were increased in the $\mathrm{KO}$ mice.

\section{TRs deletion reduces splenic hematopoietic cell content}

In comparison with Wt animals, TR $\alpha 1 / T R \beta$ KO mice show a strong decrease in spleen weight, which parallels the reduction in body weight, so that the relative spleen weight was not altered (Fig. 2A). Flow cytometry was used to score spleen cellularity (Supplementary Fig. 2). As shown in Fig. $2 \mathrm{~B}$, spleens from TR $\alpha 1 / T R \beta \mathrm{KO}$ mice presented a loss of cells, which was less pronounced, but still significant, when normalized to the spleen weight or body weight (Fig. 2B). No gross differences in spleen morphology were detected (Fig. 2C), although histopathological studies demonstrated an evident reduction of the cortical lymphoid follicles in TR-deficient mice with respect to the $\mathrm{Wt}$ animals, with a concomitant expansion of the sinusoids and splenic cords of the red pulp. Moreover, the polarized pattern of Picrosirius red staining for the evaluation of connective tissue organization demonstrated a normal structure and arrangement of the conjunctive cords in $\mathrm{KO}$ animals.

TER119 and CD45 cell-surface markers were again used to identify the two major splenic cell populations. In addition to a significant fall in the number of total and relative $\mathrm{CD} 45^{+}$cells, a decrease of TER119+ cell number was also observed in the spleens of TR $\alpha 1 / \mathrm{TR} \beta \mathrm{KO}$ mice (Fig. 2D). Therefore a loss of both cell populations can account for the reduced spleen cellularity in TR $\alpha 1 / T R \beta$-deficient mice.

Hypothyroidism also induced a substantial decrease of spleen weight, even stronger than the reduction in body weight, so that the relative spleen weight was also decreased, at difference with the normal value found in mice lacking TR $\alpha 1$ and TR $\beta$ (Fig. 3). In addition, a reduction of spleen cellularity and number of CD45+ and TER119+ cells was also observed in hypothyroid mice (Fig. 3C and E). Histopathological studies showed changes in hypothyroid mice that were more evident than those observed in TR-deficient mice (Fig. 3E). Hypothyroid spleens exhibited a noticeable reduced size 


\begin{tabular}{l|l|l|l|l|}
$\begin{array}{l}\text { Journal of } \\
\text { Endocrinology }\end{array}$ & $\begin{array}{l}\text { Á Sánchez, C Contreras- } \\
\text { Jurado et al. }\end{array}$ & $\begin{array}{l}\text { Thyroid hormone receptors } \\
\text { and hematopoiesis }\end{array}$ & $\mathbf{2 4 4 : 1}$ & $\mathbf{8 7}$ \\
\hline
\end{tabular}
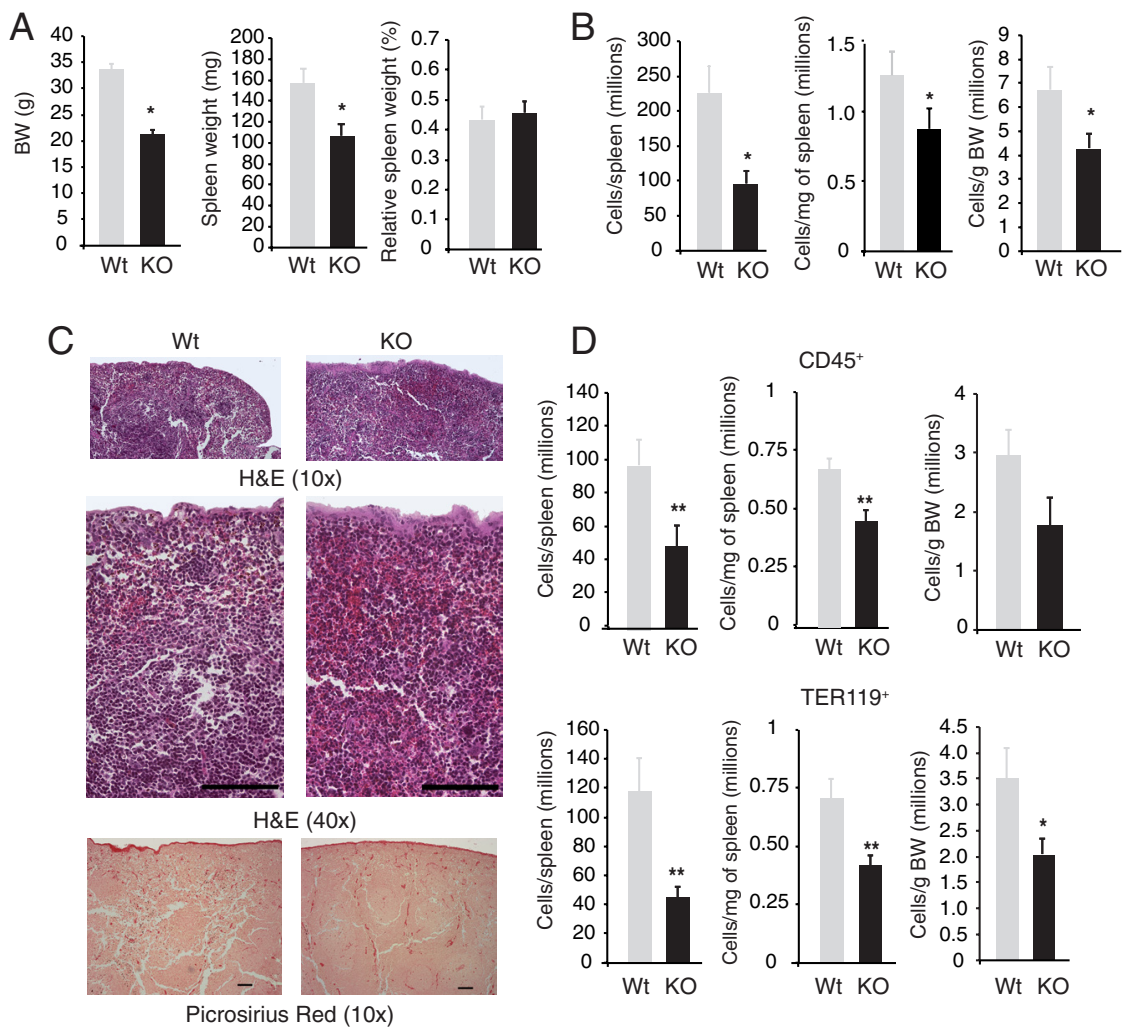
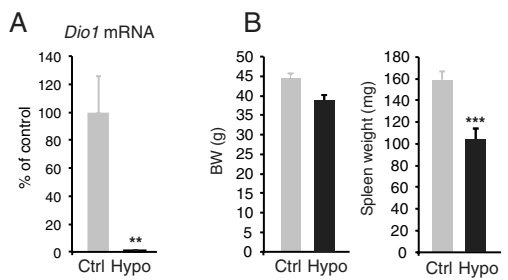

$\mathrm{D}$

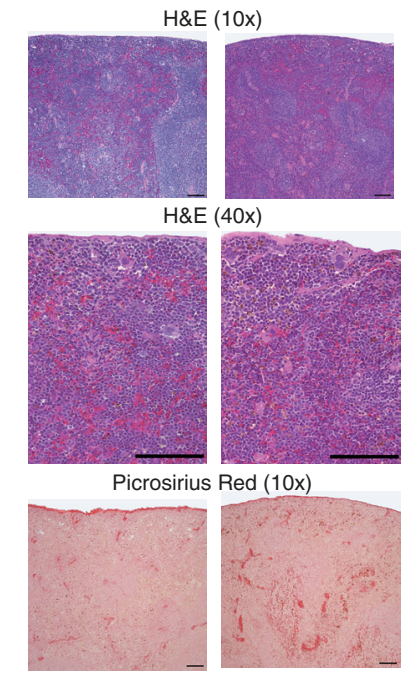

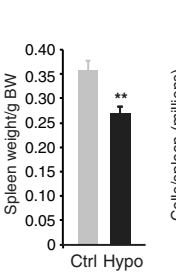
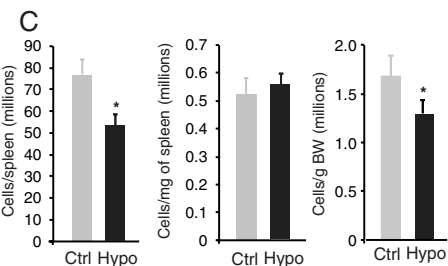

$E$
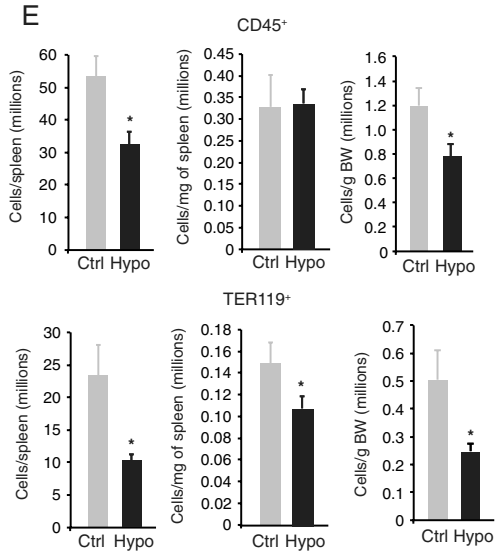

\section{Figure 3}

Spleen cellularity in hypothyroid mice. (A) Hepatic deiodinase $1 \mathrm{mRNA}$ levels in control mice (Ctrl) and in mice fed a low iodine diet supplemented with antithyroidal drugs (Hypo) for 1 month $(n=10)$. Data (means \pm S.E.) are expressed relative to the values obtained in the control animals. (B) Body weight, spleen weight and relative spleen weight with respect to the body weight in control and hypothyroid mice. (C) Total and relative splenic cellularity analyzed by flow cytometry in both groups of animals. Data are means \pm s.E. (D) Representative histology of spleens from control and hypothyroid mice analyzed by H\&E staining at $10 \times$ and $40 \times$ magnification (upper panels) and Picrosirius red staining at $10 \times$ magnification (lower panels). Bars $=100 \mu \mathrm{M}$. (E) Total number of CD45+ and TER119+ splenic cells and number of cells relative to spleen weight and relative to $\mathrm{BW}$ in control and hypothyroid animals. Data are means \pm S.E. 
of the lymphoid follicles with minimal or absent germinal centers, as well as a clear decrease of the interfollicular red pulp and a lower cellularity of the sinusoids and splenic cords, in concordance with the marked spleen hypotrophy. Picrosirius red staining confirmed the collapse of spleen architecture with thicker and closer conjunctive cords and less splenic tissue between cords.

In order to characterize the major splenic CD45+ subpopulations affected by TR $\alpha 1 / \operatorname{TR} \beta$ deletion or hypothyroidism in mice, after red cells lysis, splenocytes were stained with anti-B220, CD3 and F4/80 antibodies to identify B-cells, T-cells and macrophages, respectively. As shown in Fig. 4A, only the total and relative numbers of B-lymphocytes were significantly reduced in the spleens of KO mice. This result is in accordance with the diminished lymphoid follicles in these animals and agrees with previous reports demonstrating that the B-cell population is reduced in hypothyroid and $T R \alpha \mathrm{KO}$ mice (Montecino-Rodriguez et al. 1996, Foster et al. 1999, Arpin et al. 2000). In addition, both the B- and T-cell populations were reduced in the hypothyroid mice (Fig. 4B).

There are a number of cytokines that are not only released by hematopoietic cells but also exert profound effects on their generation and maturation (Metcalf 2008). Since we have previously shown that TR $\alpha 1 / T R \beta$ KO mice present reduced levels of several hepatic and circulating cytokines (Contreras-Jurado et al. 2016), we measured transcript levels of a panel of cytokines in these animals, finding that mRNAs for some key cytokines are reduced in the spleens of $\mathrm{KO}$ mice compared with those of $\mathrm{Wt}$ animals (Fig. 4C). However no changes in mRNA levels of Bmp4, with a key role in hematopoiesis (Kirmizitas et al. 2017) or the BMP-antagonist Twsg1 were found in mice devoid of TR $\alpha 1$ and TR $\beta$.

An increased rate of apoptosis could explain, at least in part, the drop in the number and frequency of B lineage cells in the spleen of TR $\alpha 1 / T R \beta \mathrm{KO}$ mice. To analyze this possibility, the frequency of apoptotic cells was determined by measuring DAPI and Annexin V staining. A reduction in the percentage of live $\mathrm{CD} 45^{+}$splenic cells (DAPI-/Annexin $\mathrm{V}^{-}$), corresponding to an increase in

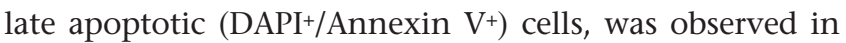
the spleen of $\mathrm{KO}$ animals. This change was attributable to increased apoptosis of the B-cell population, whereas increased cell death of T-cells or macrophages was not observed (Supplementary Fig. 3).

The expression of the surface marker CD71 and forward scatter (FSC) was used to identify, within the total splenic TER119+ cells, the different erythroblast population(s) that could account for the decrease in erythroid lineage
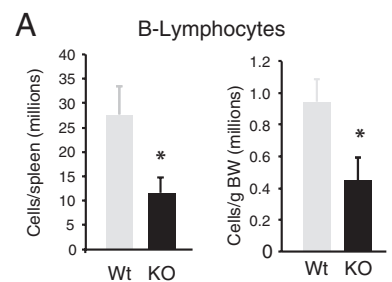

B
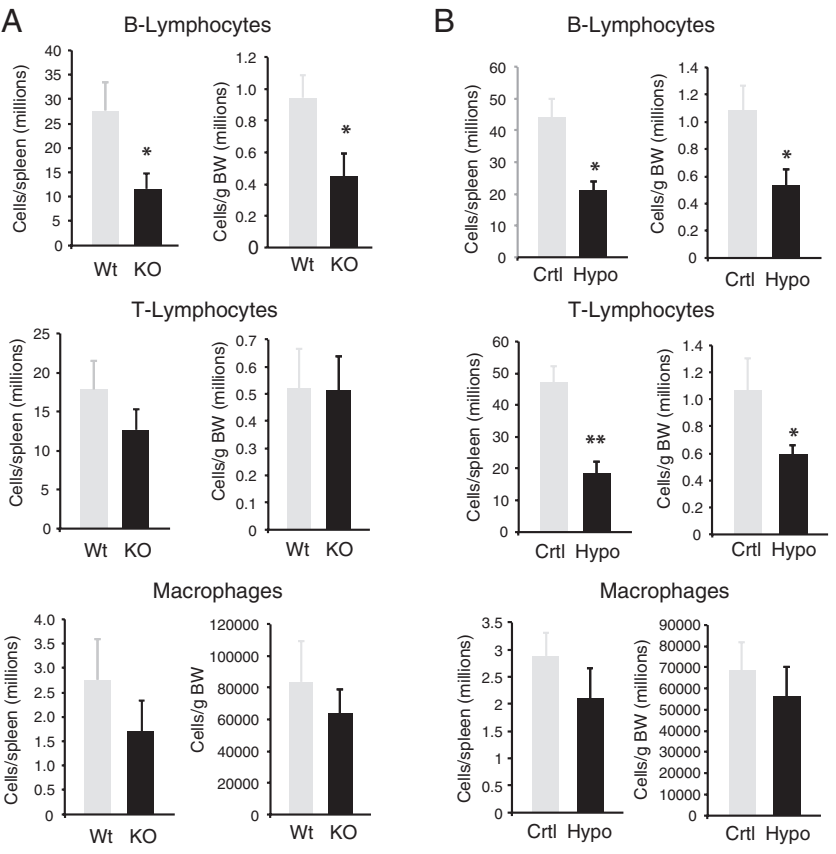

Macrophages
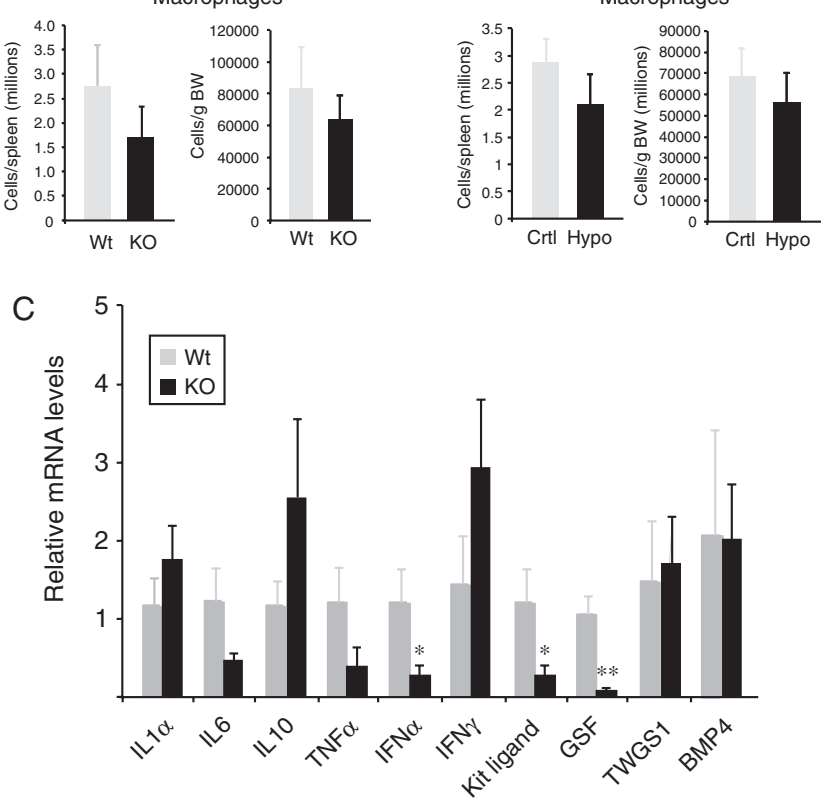

Figure 4

Reduced splenic B-cell population and cytokines expression in TR-deficient mice. (A) Absolute and relative number of B-lymphocytes $\left(C D 19^{+}\right)$, T-lymphocytes $\left(C^{2} 3^{+}\right)$, and macrophages $\left(F 4 / 80^{+}\right)$in the spleens of Wt $(n=7)$ and TR $\alpha 1 / T R \beta \mathrm{KO}(n=9)$ mice determined by flow cytometry after lysis of RBCs. (B) Similar results in a group of control $(n=4)$ and hypothyroid $(n=5)$ mice. (C) Total RNA was isolated from spleens of $\mathrm{Wt}$ $(n=5)$ and TR $\alpha 1 / T R \beta \mathrm{KO}$ mice $(n=6)$ and transcript levels for interleukin $1 \alpha$ (IL1 $\alpha)$, interleukin 6 (IL6), interleukin 10 (IL10), tumor necrosis factor $\alpha$ (TNF $\alpha)$, interferon $\alpha$ (IFN $\alpha)$, interferon $\gamma$ (IFN $\gamma)$, twisted gastrulation homolog 1 (TWGS1) and bone morphogenetic protein 4 (BMP4) were measured by RT-qPCR. In all panels data are means \pm s.E.

cells in TR $\alpha 1 /$ TR $\beta$-deficient mice (Supplementary Fig. 2). CD71/Ter119 staining identifies a developmental sequence that corresponds to increasingly mature erythroblasts. $\mathrm{CD} 71^{+}$cells are subdivided into less mature, large basophilic Ery A erythroblasts (CD71+/Ter119+/FSChigh), smaller more mature polychromatic Ery B erythroblasts (CD71+/Ter119+/FSClow) and acidophilic late Ery C erythroblasts characterized by loss of CD71 expression 
(CD71-/TER119+) (Supplementary Fig. 2). Figure 5 shows that TRs deletion, as well as hypothyroidism, reduces the number of the more differentiated Ery $C$ subset, which also corresponds to the majority of the splenic TER119+ cell population. In contrast, the total number of Ery A and Ery B cells is not decreased, and rather the relative number of the Ery B subpopulation is increased in the spleen of TR $\alpha 1 / T R \beta \mathrm{KO}$ and hypothyroid mice (Fig. 5A and B). These changes are not related to changes in apoptosis of the different RBC subpopulations, which was very low and similar in all groups (Supplementary Fig. 4).

GATA1 and KLF-9 transcription factors have been recently proposed to be critical mediators of the effects of the thyroid hormones in erythropoiesis (Park et al. 2017, Zhang et al. 2017). mRNA levels for Klf9, a well-known TR-target gene (Cvoro et al. 2015, Denver \& Williamson 2009), were diminished in the spleen of $T R \alpha 1 / T R \beta$ mice with respect to those of Wt mice (Fig. 5C). Surprisingly, and in contrast with the results obtained in the spleen of hypothyroid mice (Fig. 5D) or in mice expressing a dominant-negative TR $\alpha 1$ (Park et al. 2017), Gata1 mRNA levels were not reduced in TR $\alpha 1 / T R \beta$-deficient animals, and the same occurred with transcript levels of HIF $1 \alpha$ and HIF $2 \alpha$ genes, also described to be induced by thyroid hormones and to play an important role in erythropoiesis (Otto \& Fandrey 2008), which are reduced in hypothyroid but not in $\mathrm{KO}$ mice (Fig. 5C and D).

\section{Bone marrow erythropoiesis and leukopoiesis in TR-deficient mice}

The finding that TR $\alpha 1 / T R \beta$ KO mice are not anemic, despite having an important reduction in late erythroblast numbers in the spleen, suggests that this defect may be compensated by another erythropoietic organ. Therefore, we next analyzed the RBC subpopulations in the BM of these animals. The total number of TER119+ cells was diminished in TR-deficient mice. However, when corrected by the body weight, the decrease in the number of TER119+ cells was no longer observed (Fig. 6A). Interestingly, the number of pro-erythroblasts (ProE cells, CD71+/TER119low) was lower in TR $\alpha 1 / T R \beta \mathrm{KO}$ mice than in normal mice, and the
A

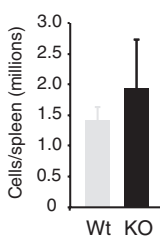

Ery A

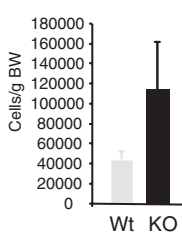

Ery B

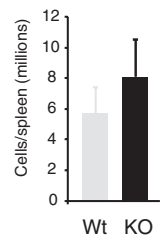

Wt KO
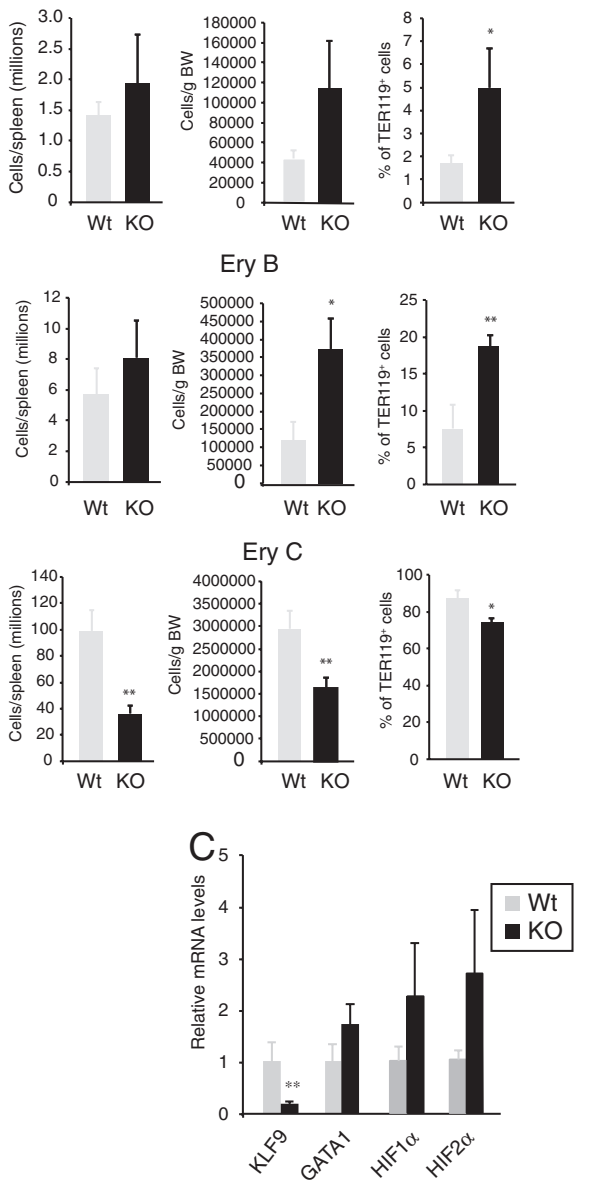

B
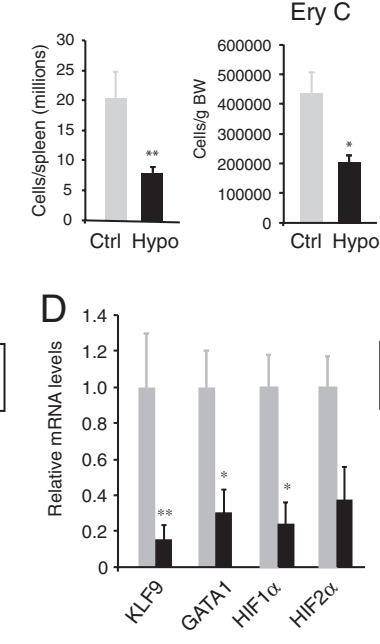

Ery A
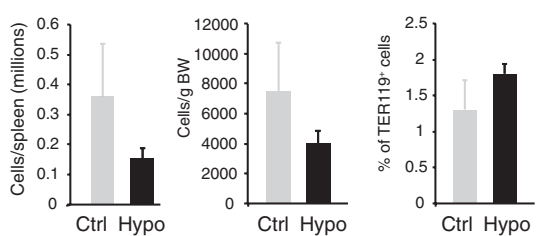

Ery B
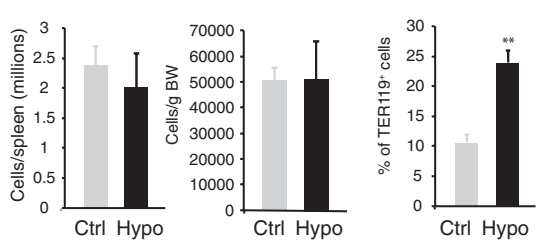

Ery C

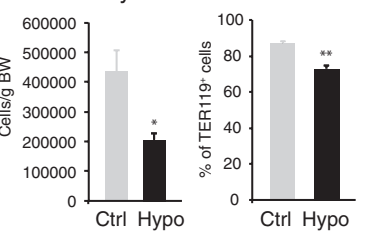

Ctrl.

- Hypo https://joe.bioscientifica.com https://doi.org/10.1530/JOE-19-0339
(C) 2020 Society for Endocrinology Published by Bioscientifica Ltd. Printed in Great Britain

\section{Figure 5}

Splenic erythroid populations and erythropoietic transcription factors in mice devoid of TRs. (A) Absolute and relative number of Ery A, Ery B, and Ery $C$ in spleens from $\mathrm{Wt}(n=5)$ and TR $\alpha 1 / T R \beta \mathrm{KO}$ $(n=6)$ mice. The percentage of each erythroblast subpopulation with respect to the total TER119+ splenic cells is illustrated at the right panels. (B) Erythroblast subpopulations in control $(n=4)$ and hypothyroid $(n=5)$ spleens. Data are means \pm S.E. (C) Transcript levels for the erythopoietic transcription factors KIf9, Gata1, Hif1 $\alpha$ and Hif2 $\alpha$ in the spleen of $\mathrm{Wt}(n=4)$ and KO $(n=6)$ mice. Data are expressed relative to the levels obtained in $\mathrm{Wt}$ mice and are means \pm S.E. (D) mRNA levels for the same transcription factors in hypothyroid spleens $(n=5)$, relative to the values obtained in their corresponding controls. 
same occurred with the more immature Ery A erythroblast subpopulation that, in contrast with the results obtained in the spleen, was also decreased. However, this reduction was reversed in the more differentiated erythroid lineage cells, and Ery B and Ery C subpopulations were no longer reduced in the TR-deficient mice, with Ery $\mathrm{C}$ cells even representing an increased percentage within the BM cells in these animals (Fig. 6A). This change in the production of erythroid cells by the BM could account at least in part for the normal RBC count, compensating the splenic erythropoietic defect. Gata1 and Klf9 mRNA levels were also measured in the $\mathrm{BM}$ of TR $\alpha 1 / T R \beta \mathrm{KO}$ and Wt mice. As shown in Fig. 5B, a reduction of the transcript for Klf9 was again found in the BM of the KO mice, while Gata1, Hif1 $\alpha$ and Hif $2 \alpha$ transcripts were not reduced in these animals, showing rather a tendency to be increased.

A significant loss of absolute and relative $\mathrm{CD} 45^{+}$cells was observed in the BM of TR $\alpha 1$ and TR $\beta$-deficient mice (Fig. 7). After lysis of the red blood cells, the total number of B-cells, macrophages, monocytes and neutrophils, gated as indicated in Supplementary Fig. 5A, was also lower in these animals than in Wt animals but, as also observed in the spleen, only the B-lymphocyte subpopulation was significantly diminished when the cell number was corrected by BW. In addition, monocyte numbers were similar in both groups and, consequently, the percentage of this subpopulation of cells was increased in the BM of TR-deficient mice.

Lymphopoiesis in the BM is a complex process involving several differentiation steps. B-cell specification initiates at the pre-pro-B stage, passing to pro-B and then to pre-B stages, characterized within the low $\mathrm{B} 220^{+}$cell population by their differential expression of CD24 and CD249. Pre-B cells maturation further progresses giving rise to different B-cell precursors with higher B200 expression (immature B-cells, transitional B-cells, and early and late mature cells), which can be segregated based on IgM and IgD expression (Hardy \& Hayakawa 2001, Rumfelt et al. 2006, Pillai \& Cariappa 2009, Velten et al. 2017). To further determine the defect in B-cell lymphopoiesis in the BM of TR $\alpha 1 / \mathrm{TR} \beta$ $\mathrm{KO}$ mice, we have identified the different progenitor B-cell subsets. Supplementary Figure 5B shows the gating strategy used. Both the total number $\mathrm{B}^{2} 20^{+}$cells (Fig. 8A), as well as the absolute number of cells at the different stages of $\mathrm{B}$-cell development, were significantly reduced in the BM of mice lacking TRs with respect to Wt (Fig. 8B and C). However, when corrected by body weight a reduction was found from the pre-B stage with no significant change of the earliest precursors. Therefore, the B lineage deficiency in the TR $\alpha 1 / T R \beta \mathrm{KO}$ mice appears to be due to an effect in already committed B-cell precursors.
A
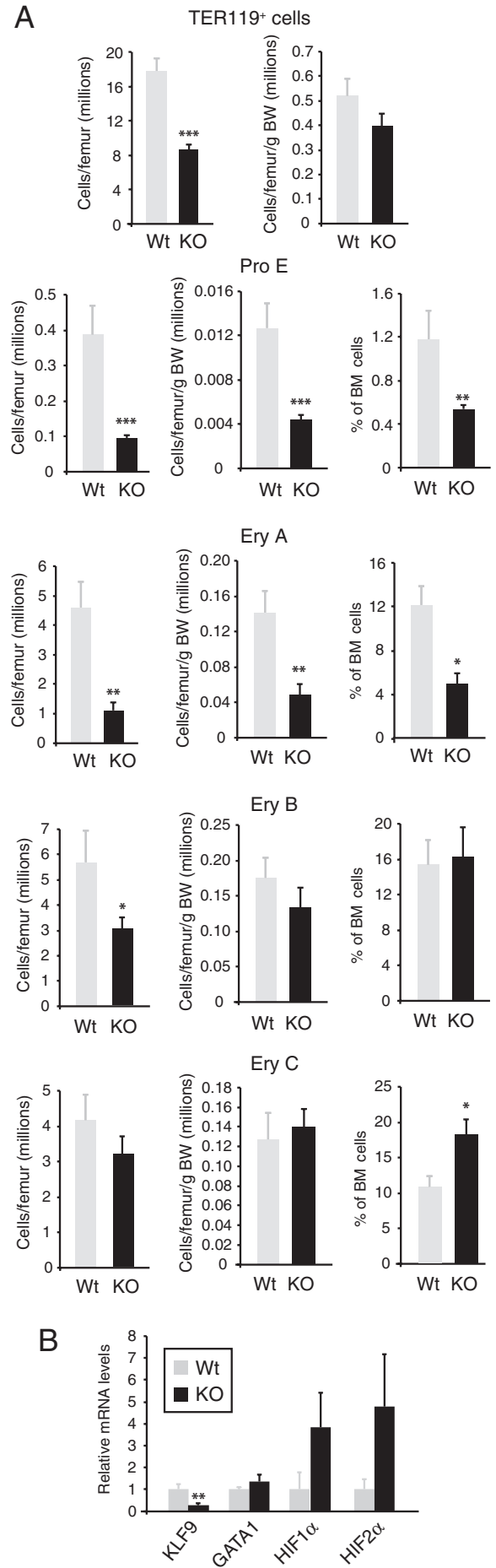

\section{Figure 6}

Bone marrow erythropoiesis in TR-deficient mice. (A) Absolute number of cells/femur and relative numbers (corrected by BW) of TER119+ BM cells, proerythroblasts (Pro E), and Ery A, Ery B and Ery C erythroblasts subpopulations in Wt $(n=6)$ and TR $\alpha 1 / \operatorname{TR} \beta \mathrm{KO}(n=7)$ mice. The percentage of each population with respect to the total number of BM cells is illustrated at the right panels. Data are means \pm S.E. (B) Transcript levels of erythroid transcription factors in the BM of Wt $(n=4)$ and $\mathrm{KO}(n=6)$ mice. Data are means \pm S.E. and are expressed relative to the values obtained in the Wt animals. 
A
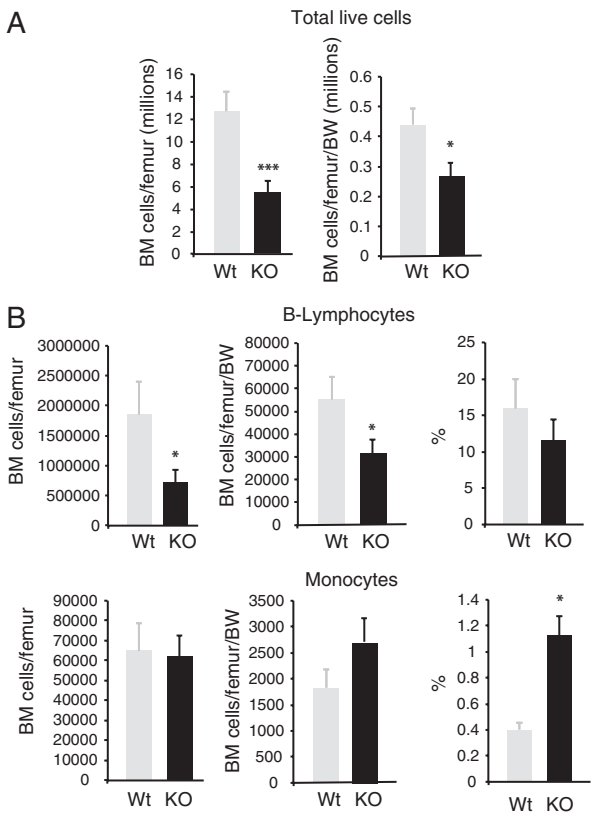

Macrophages
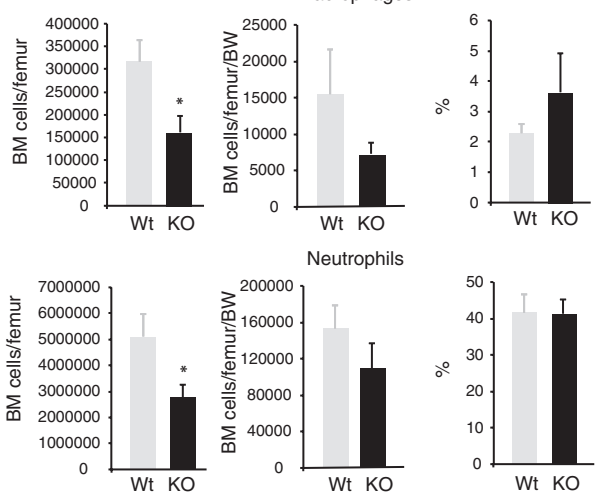

Figure 7

Bone marrow B-cells are decreased in TR-deficient mice. (A) Total and relative numbers of CD45+ BM cells after RBC lysis in Wt $(n=6)$ and TR $\alpha 1 / T R \beta \mathrm{KO}(n=9)$ mice. (B) CD45+ BM cell subpopulations were identified by flow cytometry by expression of B220 (B-lymphocytes), CD115 (monocytes), F4/80 (macrophages) and Ly6G (neutrophils). Total number of cells/femur (left panels), number of cells relative to BW (middle panels) and the percentage of cells respect to total cells (right panels) are represented as means \pm S.E.

\section{Discussion}

The aim of this study has been to determine the status of key cell types from the three major branches of hematopoietic cells (erythroid cells, lymphoid cells and myeloid cells) in mice devoid of all known thyroid hormone receptors with capacity to bind thyroid hormones and in hypothyroid mice. Our results show that deregulation of thyroid hormone action, due to either lack of the receptors or their ligand, mainly affects erythroid and lymphoid cell lineages. Furthermore, we found that the overall hematopoietic phenotype is milder
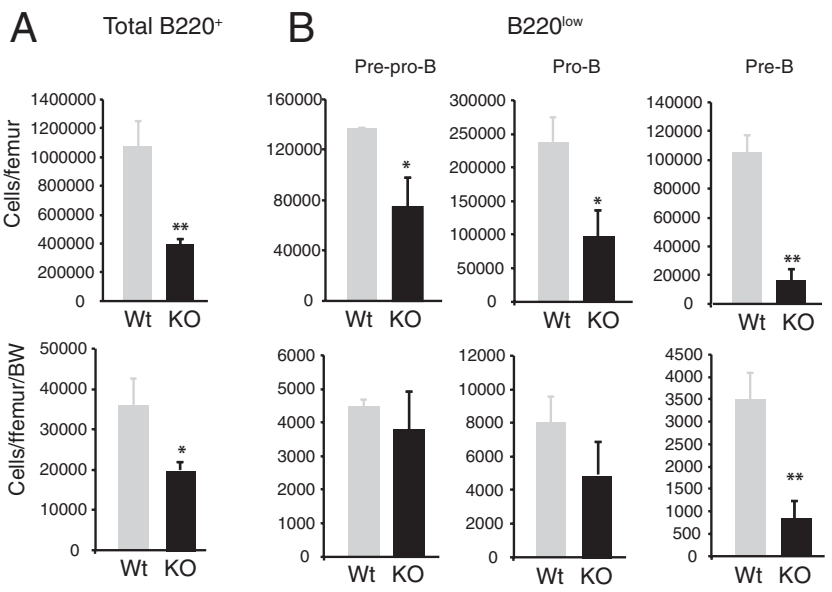

C
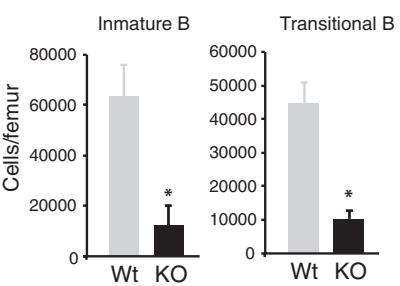

B220 high
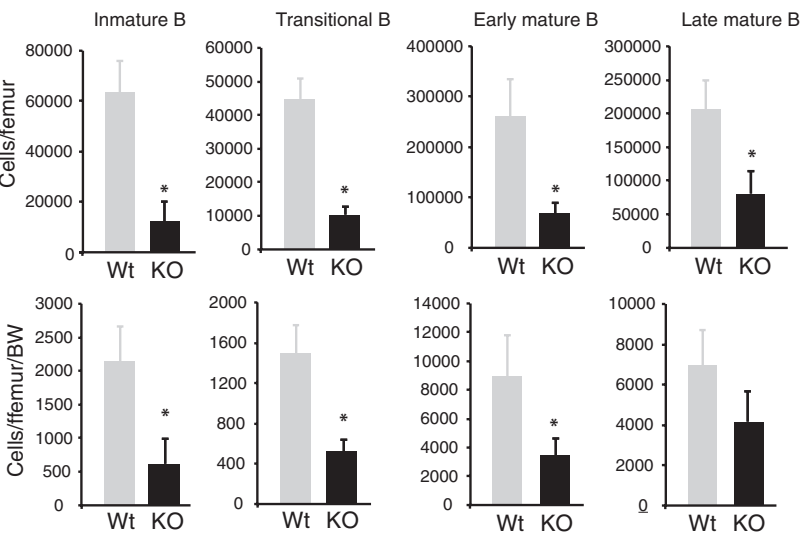

Figure 8

B-cell differentiation in the bone marrow of TR-deficient mice. (A) Total numbers of low and high B220+ BM cells and numbers B220+ cells relative to BW after RBC lysis in Wt and TR $\alpha 1 / T R \beta \mathrm{KO}$ mice $(n=3)$. (B) Total and relative number of $\mathrm{B} 220^{\text {low }}$ cells, including pre-pro, pro-, and pre-B cells, are represented in the upper and lower panels, respectively. (C) Total and relative number of increasingly mature forms of B-cells precursors with high B220 expression (immature, transitional, early mature and late mature B-cells). Data are means \pm S.E.

in the absence of the receptors than in the absence of the hormone, providing a functional role to the unoccupied receptors in this process.

It has been known for a long time that hypothyroidism is often associated with anemia, but ageing mice lacking the receptors do not show significant anemia, in contrast with age-paired matched animals made hypothyroid for only 1 month. TR-deficient animals indeed present an alteration in the erythroid cell lineage with an abnormal distribution of erythroblasts subpopulations, including a reduction in the more mature erythroblasts forms (Ery C) in secondary erythroid organs such as the spleen, but this defect appears to be compensated by the normal production of erythroblasts in the BM. In contrast with the results obtained in mice lacking both TR $\alpha 1$ and TR $\beta$, 
mild anemia secondary to defects in erythroid differentiation is found in mice lacking only TR $\alpha$ (Kendrick et al. 2008) or in $T R \alpha 1^{P V /+}$ mice expressing a dominant negative receptor (Park et al. 2017).

The finding that animals lacking TR $\alpha$ and TR $\beta$ appear to show a less altered erythropoiesis than that found in the absence of hormone could be related to the transcriptional effects of the unoccupied TR $\beta$. It has been recently shown that Gata1, a key factor in erythropoiesis (Gutierrez et al. 2008, Mancini et al. 2012) is a direct TR-target gene. In TR $\alpha 1^{P V /+}$ mice, as well as in hypothyroid mice, Gata1 gene expression is impaired, resulting in concurrent repression of other genes involved in the maturation of erythrocytes (Park et al. 2017). In contrast, Gata1 expression was not reduced in TR $\alpha 1 / T R \beta$ KO mice. This difference might be attributed to the repressive action of unoccupied $\operatorname{TR} \beta$ on the Gata1 gene. Furthermore, two TR-binding sites were identified on the Gata1 promoter, one mediating positive effects and one mediating negative effects of the thyroid hormone (Park et al. 2017). That TR $\beta$ and TR $\alpha 1$ could arbitrate a differential regulation on these elements is also an intriguing possibility that remains to be investigated.

Other recent study has identified Klf9 as a TR-target gene potentially responsible for the hematopoietic dysfunction found in hypothyroidism, acting as a mediator between the thyroid axis and erythroid maturation (Zhang et al. 2017). This has led to the hypothesis that KLF9 could represent the long-sought factor that regulates the last steps of erythroid maturation downstream of GATA1 (Migliaccio 2017). Interestingly, Klf9 gene expression was also impaired in the spleen of mice devoid of TRs with a deficiency of mature erythroblasts. However, this transcript was also reduced in the BM, where the late erythroblast population was not decreased. Thus, other still unidentified genes should be responsible for the differential effect of TR deletion on erythroblast differentiation in BM and spleen, suggesting that the different cellular environments could have a profound impact in the regulation of genes responsible for TRs action on erythropoiesis. The lack of the repressive effects of the unliganded receptors could also be involved in the differential effects of hormone versus receptors deficiency (Flamant et al. 2002, Flamant \& Samarut 2003), and to be related to the mild effects of receptor deletion in erythropoiesis. However, given the complex physiology in the whole animal, we cannot dismiss the possibility that other mechanisms involving tissue interactions and indirect cellular signaling or other means of compensation could be responsible for the observed eryhtroid phenotype in $T R \alpha 1 / T R \beta$-deficient mice.

(C) 2020 Society for Endocrinology Published by Bioscientifica Ltd. Printed in Great Britain
Deletion of $\operatorname{TR} \alpha 1$ and $\operatorname{TR} \beta$ also affects the B-cell population. B-lymphocyte numbers were consistently reduced in the blood, spleen and $\mathrm{BM}$ of $T R \alpha 1 / \mathrm{TR} \beta \mathrm{KO}$ animals, in agreement with the finding that thyroid hormone deficiency impairs B-lymphocyte production in humans and mice (Montecino-Rodriguez et al. 1996, 1997, Foster et al. 1999, Dorshkind \& Horseman 2000, Grymula et al. 2007, Zhang et al. 2017), while B-cell progenitors and mature B-cells are increased in the BM of T3-treated mice (Bloise et al. 2014). We have performed a detailed study of B-cell development in the BM of TR $\alpha 1 / T R \beta$ deficient mice, finding a strong defect of the pre-B cells and more mature stages. At the immature B-cell stage, cells can also exit the BM to enter the circulation and populate secondary lymphoid organs, such as the spleen, where final mature B-cell phenotypes are also generated (Pillai \& Cariappa 2009). Thus, the decreased number of circulating B-cells in TR-deficient mice could result from a reduced generation in both hematopoietic organs. In addition, the reduced B-cell cellularity observed in the TR $\alpha 1 / T R \beta \mathrm{KO}$ mice appears also to result from an increased sensitivity to programmed cell death, as manifested by an increase in the number of late apoptotic cells found in the spleen of these animals.

A similar reduction of B-cells was found in hypothyroid and $T R \alpha 1 / T R \beta \mathrm{KO}$ mice. It has been suggested that the action of the thyroid hormones on B-lymphopoiesis results from compromised generation of progenitor B-cells (Montecino-Rodriguez et al. 1997) and appears to be mediated by binding to TR $\alpha$ (Arpin et al. 2000). Although Arpin et al. used young mice, the similarity of our results with those obtained in TR $\alpha \mathrm{KO}$ mice is in agreement with the hypothesis that TR $\alpha 1$ is crucial in mediating the effects of the hormones on B-lymphocytes.

At difference with hypothyroid mice, mice lacking TRs show an increased number of circulating monocytes, which is in consonance with the increased number of monocytes/femur detected in these mice. Whether or not this represents a developmental change and/or altered production, differentiation or migration to secondary lymphoid organs in the absence of the receptors remains to be established.

Spleen hypotrophy, as well as changes in splenic architecture, was more evident in hypothyroid than in TR-deficient mice. Interestingly, we found a decrease of splenic T-cells in adult hypothyroid mice, which was not observed in TR $\alpha 1 / T R \beta$ KO mice. Therefore, deletion of TRs causes again a milder phenotype than the one produced by the deficiency of thyroid hormones.

The genes and mechanisms by which TRs regulate splenic cell populations have not yet been examined. 
Our data show that the spleen of $T R \alpha 1 / T R \beta$ KO mice present a deficiency of several cytokines with important roles not only in immune and inflammatory responses, but also in hematopoiesis (Pestka et al. 2004, Parcells et al. 2006, Metcalf 2008). Since splenic cytokines can be locally produced, this reduction could result from their impaired number and/or function of the immune cells in TR $\alpha 1 / T R \beta$ KO mice. The contribution of these cytokines, as well as other molecules to the effects of the receptors in the spleen remains to be investigated.

In summary, our results show that mice lacking both TR $\alpha 1$ and TR $\beta$ exhibit a hematopoietic and splenic phenotype less severe than that found in hypothyroidism. Although we cannot rule out other mechanism/s, our results are also compatible with the hypothesis that the unoccupied TRs could have a repressive effect on hematopoiesis, likely due to inhibition of hematopoietic gene expression.

\section{Supplementary materials}

This is linked to the online version of the paper at https://doi.org/10.1530/ JOE-19-0339.

\section{Declaration of interest}

The authors declare that there is no conflict of interest that could be perceived as prejudicing the impartiality of the research reported.

\section{Funding}

This work was supported by grant SAF2017-83289-R and SAF2017-90604REDT (Ministerio de Ciencias, Innovación y Universidades) and B2017/ BMD-3724 (Comunidad de Madrid). The cost of this publication has been paid in part by FEDER Funds.

\section{Acknowledgments}

The authors thank Carmen Sanchez-Palomo for histological methods.

\section{References}

Angelin-Duclos C, Domenget C, Kolbus A, Beug H, Jurdic P \& Samarut J 2005 Thyroid hormone T3 acting through the thyroid hormone alpha receptor is necessary for implementation of erythropoiesis in the neonatal spleen environment in the mouse. Development 132 925-934. (https://doi.org/10.1242/dev.01648)

Aranda A \& Pascual A 2001 Nuclear hormone receptors and gene expression. Physiological Reviews 81 1269-1304. (https://doi. org/10.1152/physrev.2001.81.3.1269)

Aranda A, Alonso-Merino E \& Zambrano A 2013 Receptors of thyroid hormones. Pediatric Endocrinology Reviews 11 2-13.

Arpin C, Pihlgren M, Fraichard A, Aubert D, Samarut J, Chassande O \& Marvel J 2000 Effects of T3R alpha 1 and T3R alpha 2 gene deletion on T and B lymphocyte development. Journal of Immunology 164 152-160. (https://doi.org/10.4049/jimmunol.164.1.152)

Bian Z, Shi L, Guo YL, Lv Z, Tang C, Niu S, Tremblay A, Venkataramani M, Culpepper C, Li L, et al. 2016 CD47-Sirpalpha interaction and IL-10 constrain inflammation-induced macrophage phagocytosis of healthy self-cells. PNAS 113 E5434-E5443. (https:// doi.org/10.1073/pnas.1521069113)

Bloise FF, Oliveira FL, Nobrega AF, Vasconcellos R, Cordeiro A, Paiva LS, Taub DD, Borojevic R, Pazos-Moura CC \& Mello-Coelho VD 2014 High levels of circulating triiodothyronine induce plasma cell differentiation. Journal of Endocrinology 220 305-317. (https://doi. org/10.1530/JOE-13-0315)

Bochukova E, Schoenmakers N, Agostini M, Schoenmakers E, Rajanayagam O, Keogh JM, Henning E, Reinemund J, Gevers E, Sarri M, et al. 2012 A mutation in the thyroid hormone receptor alpha gene. New England Journal of Medicine 366 243-249. (https:// doi.org/10.1056/NEJMoa1110296)

Bremner AP, Feddema P, Joske DJ, Leedman PJ, O'Leary PC, Olynyk JK \& Walsh JP 2012 Significant association between thyroid hormones and erythrocyte indices in euthyroid subjects. Clinical Endocrinology $\mathbf{7 6}$ 304-311. (https://doi.org/10.1111/j.1365-2265.2011.04228.x)

Contreras-Jurado C, Alonso-Merino E, Saiz-Ladera C, Valino AJ, Regadera J, Alemany S \& Aranda A 2016 The thyroid hormone receptors inhibit hepatic interleukin- 6 signaling during endotoxemia. Scientific Reports 6 30990. (https://doi.org/10.1038/srep30990)

Cvoro A, Devito L, Milton FA, Noli L, Zhang A, Filippi C, Sakai K, Suh JH, H Sieglaff D, Dhawan A, et al. 2015 A thyroid hormone receptor/KLF9 axis in human hepatocytes and pluripotent stem cells. Stem Cells $\mathbf{3 3}$ 416-428. (https://doi.org/10.1002/stem.1875)

Denver RJ \& Williamson KE 2009 Identification of a thyroid hormone response element in the mouse Kruppel-like factor 9 gene to explain its postnatal expression in the brain. Endocrinology $1503935-3943$. (https://doi.org/10.1210/en.2009-0050)

Dorshkind K \& Horseman ND 2000 The roles of prolactin, growth hormone, insulin-like growth factor-I, and thyroid hormones in lymphocyte development and function: insights from genetic models of hormone and hormone receptor deficiency. Endocrine Reviews $\mathbf{2 1}$ 292-312. (https://doi.org/10.1210/edrv.21.3.0397)

Dumitrescu AM \& Refetoff S 2013 The syndromes of reduced sensitivity to thyroid hormone. Biochimica and Biophysica Acta 1830 3987-4003. (https://doi.org/10.1016/j.bbagen.2012.08.005)

Erdogan M, Kosenli A, Ganidagli S \& Kulaksizoglu M 2012 Characteristics of anemia in subclinical and overt hypothyroid patients. Endocrine Journal 59 213-220. (https://doi.org/10.1507/endocrj.ej11-0096)

Flamant F \& Samarut J 2003 Thyroid hormone receptors: lessons from knockout and knock-in mutant mice. Trends in Endocrinology and Metabolism 14 85-90. (https://doi.org/10.1016/S1043-2760(02)00043-7)

Flamant F, Poguet AL, Plateroti M, Chassande O, Gauthier K, Streichenberger N, Mansouri A \& Samarut J 2002 Congenital hypothyroid Pax8(-/-) mutant mice can be rescued by inactivating the TRalpha gene. Molecular Endocrinology 16 24-32.

Forrest D, Erway LC, Ng L, Altschuler R \& Curran T 1996a Thyroid hormone receptor beta is essential for development of auditory function. Nature Genetics 13 354-357. (https://doi.org/10.1038/ ng0796-354)

Forrest D, Hanebuth E, Smeyne RJ, Everds N, Stewart CL, Wehner JM $\&$ Curran T $1996 b$ Recessive resistance to thyroid hormone in mice lacking thyroid hormone receptor beta: evidence for tissue-specific modulation of receptor function. EMBO Journal 15 3006-3015. (https://doi.org/10.1002/j.1460-2075.1996.tb00664.x)

Foster MP, Montecino-Rodriguez E \& Dorshkind K 1999 Proliferation of bone marrow pro-B cells is dependent on stimulation by the pituitary/thyroid axis. Journal of Immunology 163 5883-5890.

Fraichard A, Chassande O, Plateroti M, Roux JP, Trouillas J, Dehay C, Legrand C, Gauthier K, Kedinger M, Malaval L, et al. 1997 The T3R alpha gene encoding a thyroid hormone receptor is essential for 
post-natal development and thyroid hormone production. EMBO Journal 16 4412-4420. (https://doi.org/10.1093/emboj/16.14.4412)

Franzese A, Salerno M, Argenziano A, Buongiovanni C, Limauro R \& Tenore A 1996 Anemia in infants with congenital hypothyroidism diagnosed by neonatal screening. Journal of Endocrinological Investigation 19 613-619. (https://doi.org/10.1007/BF03349027)

Gauthier K, Chassande O, Plateroti M, Roux JP, Legrand C, Pain B, Rousset B, Weiss R, Trouillas J \& Samarut J 1999 Different functions for the thyroid hormone receptors TRalpha and TRbeta in the control of thyroid hormone production and post-natal development. EMBO Journal 18 623-631. (https://doi.org/10.1093/emboj/18.3.623)

Gothe S, Wang Z, Ng L, Kindblom JM, Barros AC, Ohlsson C, Vennstrom B \& Forrest D 1999 Mice devoid of all known thyroid hormone receptors are viable but exhibit disorders of the pituitarythyroid axis, growth, and bone maturation. Genes and Development 13 1329-1341. (https://doi.org/10.1101/gad.13.10.1329)

Grymula K, Paczkowska E, Dziedziejko V, Baskiewicz-Masiuk M, Kawa M, Baumert B, Celewicz Z, Gawrych E \& Machalinski B 2007 The influence of 3,3',5-triiodo-L-thyronine on human haematopoiesis. Cell Proliferation 40 302-315. (https://doi.org/10.1111/j.13652184.2007.00435.x)

Gutierrez L, Tsukamoto S, Suzuki M, Yamamoto-Mukai H, Yamamoto M, Philipsen S \& Ohneda K 2008 Ablation of Gata1 in adult mice results in aplastic crisis, revealing its essential role in steady-state and stress erythropoiesis. Blood 111 4375-4385. (https://doi.org/10.1182/blood2007-09-115121)

Hardy RR \& Hayakawa K 2001 B cell development pathways. Annual Review of Immunology 19 595-621. (https://doi.org/10.1146/annurev. immunol.19.1.595)

Jafarzadeh A, Poorgholami M, Izadi N, Nemati M \& Rezayati M 2010 Immunological and hematological changes in patients with hyperthyroidism or hypothyroidism. Clinical and Investigative Medicine 33 E271-E279.

Jara EL, Munoz-Durango N, Llanos C, Fardella C, Gonzalez PA, Bueno SM, Kalergis AM \& Riedel CA 2017 Modulating the function of the immune system by thyroid hormones and thyrotropin. Immunology Letters 184 76-83. (https://doi.org/10.1016/j.imlet.2017.02.010)

Kawa MP, Grymula K, Paczkowska E, Baskiewicz-Masiuk M, Dabkowska E, Koziolek M, Tarnowski M, Klos P, Dziedziejko V, Kucia M, et al. 2010 Clinical relevance of thyroid dysfunction in human haematopoiesis: biochemical and molecular studies. European Journal of Endocrinology 162 295-305. (https://doi.org/10.1530/EJE-09-0875)

Kendrick TS, Payne CJ, Epis MR, Schneider JR, Leedman PJ, Klinken SP \& Ingley E 2008 Erythroid defects in TRalpha-/- mice. Blood 111 3245-3248. (https://doi.org/10.1182/blood-2007-07-101105)

Kirmizitas A, Meiklejohn S, Ciau-Uitz A, Stephenson R \& Patient R 2017 Dissecting BMP signaling input into the gene regulatory networks driving specification of the blood stem cell lineage. PNAS $\mathbf{1 1 4}$ 5814-5821. (https://doi.org/10.1073/pnas.1610615114)

Mancini E, Sanjuan-Pla A, Luciani L, Moore S, Grover A, Zay A, Rasmussen KD, Luc S, Bilbao D, O'Carroll D, et al. 2012 FOG-1 and GATA-1 act sequentially to specify definitive megakaryocytic and erythroid progenitors. EMBO Journal 31 351-365. (https://doi. org/10.1038/emboj.2011.390)

Metcalf D 2008 Hematopoietic cytokines. Blood 111 485-491. (https:// doi.org/10.1182/blood-2007-03-079681)

Migliaccio AR 2017 Miss Piggy on the catwalk again. Blood 130 2153-2154. (https://doi.org/10.1182/blood-2017-10-809640)

Montecino-Rodriguez E, Clark R, Johnson A, Collins L \& Dorshkind K 1996 Defective B cell development in Snell dwarf (dw/dw) mice can be corrected by thyroxine treatment. Journal of Immunology 157 3334-3340.
Montecino-Rodriguez E, Clark RG, Powell-Braxton L \& Dorshkind K 1997 Primary B cell development is impaired in mice with defects of the pituitary/thyroid axis. Journal of Immunology 159 2712-2719.

Moran C, Schoenmakers N, Agostini M, Schoenmakers E, Offiah A, Kydd A, Kahaly G, Mohr-Kahaly S, Rajanayagam O, Lyons G, et al. 2013 An adult female with resistance to thyroid hormone mediated by defective thyroid hormone receptor alpha. Journal of Clinical Endocrinology and Metabolism 98 4254-4261. (https://doi.org/10.1210/ jc.2013-2215)

Otto T \& Fandrey J 2008 Thyroid hormone induces hypoxia-inducible factor 1alpha gene expression through thyroid hormone receptor beta/retinoid X receptor alpha-dependent activation of hepatic leukemia factor. Endocrinology 149 2241-2250. (https://doi. org/10.1210/en.2007-1238)

Parcells BW, Ikeda AK, Simms-Waldrip T, Moore TB \& Sakamoto KM 2006 FMS-like tyrosine kinase 3 in normal hematopoiesis and acute myeloid leukemia. Stem Cells 24 1174-1184. (https://doi.org/10.1634/ stemcells.2005-0519)

Park S, Han CR, Park JW, Zhao L, Zhu X, Willingham M, Bodine DM \& Cheng SY 2017 Defective erythropoiesis caused by mutations of the thyroid hormone receptor alpha gene. PLoS Genetics 13 e1006991. (https://doi.org/10.1371/journal.pgen.1006991)

Pascual A \& Aranda A 2013 Thyroid hormone receptors, cell growth and differentiation. Biochimica and Biophysica Acta 1830 3908-3916. (https://doi.org/10.1016/j.bbagen.2012.03.012)

Pestka S, Krause CD \& Walter MR 2004 Interferons, interferon-like cytokines, and their receptors. Immunological Reviews 202 8-32. (https://doi.org/10.1111/j.0105-2896.2004.00204.x)

Pillai S \& Cariappa A 2009 The follicular versus marginal zone B lymphocyte cell fate decision. Nature Reviews: Immunology 9 767-777. (https://doi.org/10.1038/nri2656)

Pillay K 1998 Congenital hypothyroidism and immunodeficiency: evidence for an endocrine-immune interaction. Journal of Pediatric Endocrinology and Metabolism 11 757-761. (https://doi.org/10.1515/ jpem.1998.11.6.757)

Rumfelt LL, Zhou Y, Rowley BM, Shinton SA \& Hardy RR 2006 Lineage specification and plasticity in CD19-early B cell precursors. Journal of Experimental Medicine 203 675-687. (https://doi.org/10.1084/ jem.20052444)

Velten L, Haas SF, Raffel S, Blaszkiewicz S, Islam S, Hennig BP, Hirche C, Lutz C, Buss EC, Nowak D, et al. 2017 Human haematopoietic stem cell lineage commitment is a continuous process. Nature Cell Biology 19 271-281. (https://doi.org/10.1038/ncb3493)

Vitale G, Fatti LM, Prolo S, Girola A, Caraglia M, Marra M, Abbruzzese A, Gerli G \& Mari D 2010 Screening for hypothyroidism in older hospitalized patients with anemia: a new insight into an old disease. Journal of the American Geriatrics Society 58 1825-1827. (https://doi. org/10.1111/j.1532-5415.2010.03040.x)

Wikstrom L, Johansson C, Salto C, Barlow C, Campos Barros A, Baas F, Forrest D, Thoren P \& Vennstrom B 1998 Abnormal heart rate and body temperature in mice lacking thyroid hormone receptor alpha 1. EMBO Journal 17 455-461. (https://doi.org/10.1093/emboj/17.2.455)

Zavacki AM, Ying H, Christoffolete MA, Aerts G, So E, Harney JW, Cheng SY, Larsen PR \& Bianco AC 2005 Type 1 iodothyronine deiodinase is a sensitive marker of peripheral thyroid status in the mouse. Endocrinology 146 1568-1575. (https://doi.org/10.1210/ en.2004-1392)

Zhang Y, Xue Y, Cao C, Huang J, Hong Q, Hai T, Jia Q, Wang X, Qin G, Yao J, et al. 2017 Thyroid hormone regulates hematopoiesis via the TR-KLF9 axis. Blood 130 2161-2170. (https://doi.org/10.1182/blood2017-05-783043)

Received in final form 1 October 2019

Accepted 4 October 2019

Accepted Manuscript published online 4 October 2019 https://joe.bioscientifica.com https://doi.org/10.1530/JOE-19-0339 (c) 2020 Society for Endocrinology Published by Bioscientifica Ltd. Printed in Great Britain 